Article

\title{
Facing the New Situation of Religious Education in Iceland
}

\author{
Gunnar J. Gunnarsson (D) \\ School of Education, University of Iceland, 105 Reykjavik, Iceland; gunnarjg@hi.is
}

Received: 31 August 2020; Accepted: 16 October 2020; Published: 20 October 2020

\begin{abstract}
Over the last two decades, Iceland has faced rapid societal changes in many ways, and cultural and religious diversity has grown faster than ever before. This has influenced the curricula of religious education. In 2011/2013, drastic changes were made to the National Curriculum Guide, and the curricula of individual subjects were merged into larger entities. Religious education thus became a part of the social studies curriculum, together with history, geography, sociology, life skills, ethics and philosophy. The aim of this article is to explore and discuss the influences of the societal changes in Iceland on religious education in compulsory schools. As little research exists on the consequences of the changes made to the curriculum for the practice of religious education, the focus will also be on some of the research that can shed light on the changing conditions of religious education in Iceland, such as Icelanders' attitudes towards religion, and parents' attitudes towards religious education in compulsory school. Particular attention will be paid to research into young people's views towards the growing cultural and religious diversity in Iceland. The aim is to understand better the new situation of religious education in Iceland and the changes that have been made to the National Curriculum Guide.
\end{abstract}

Keywords: religious education; diversity; curriculum; parents and young people's views and attitudes

\section{Introduction}

Over the last two decades, Iceland has faced rapid societal changes in many ways. During the first decade of the twentieth century, the country has seen an economic rise, fall, and then a rise again. At the same time, cultural and religious diversity has grown faster than ever before. For most of the 20th century, Icelandic society was rather homogeneous, but in recent decades the languages, cultures and religions of Iceland's population have become increasingly diverse. The ratio of non-Icelandic citizens to the total population has changed from $1.8 \%$ in 1995 to $15.2 \%$ in 2020, out of a total population of 366,130 (Statistics Iceland 2020a). Over the past few years, there has been a rapid increase in the youngest age groups. Immigrant children and youth consequently attend most of the preschools and compulsory schools in Iceland, creating new challenges for school communities which were previously more homogeneous in terms of students' cultural diversity and languages (Ragnarsdóttir 2008). Religious diversity has also increased in recent years, with a growing number of religious organizations in Iceland. Fifteen years ago, the number of religious organizations in Iceland recognised by the Ministry of the Interior was 17; now, they number 47 . Twenty years ago, around $90 \%$ of the population belonged to The National Lutheran Church of Iceland; now, the figure is $63.47 \%$ (Statistics Iceland 2020b). Together with the growing number and diversity of religious organisations, the secularisation of the Icelandic society has increased. Now, $7.17 \%$ of the population are not registered in any religious organization, and at least one secular worldview organisation has been recognised by the Ministry of the Interior: Siðmennt-the Icelandic Ethical Humanist Association $(0.96 \%)$ (Statistics Iceland 2020b). The Church's impact on social issues and discussion has diminished 
over the last few decades, and the general public's trust in the Church is not the same as it was before the turn of the century (Gallup 2020).

With this development in mind, it is of interest to explore the ways in which such changes have influenced the curricula of religious education. In 2008, a new Compulsory School Act changed the name of the RE subject from being 'Christian knowledge, ethics and religious studies' to 'religious education' (literally 'religious studies') (Compulsory School Act 2008). In the following National curriculum guide (2011/2013), drastic changes were made, and curricula of individual subjects were merged into larger entities. Religious education thus became a part of the social studies curriculum, together with history, geography, sociology, life skills, ethics and philosophy (The Ministry of Education, Science and Culture 2013). After the National Curriculum Guide came into force in 2013, the compulsory schools in Iceland had about three years to implement the new curriculum by making their own school curriculum guide in different subject areas, including social studies. It is now timely to ask what this process has meant for religious education. The aim of this article is to explore and discuss the influences of the societal changes in Iceland on religious education, and how these changes appear in the legislation and curricula. The focus will also be on some research that can shed light on the changing conditions of religious education in Iceland, such as Icelanders' attitudes towards religion, and parents' attitudes towards religious education in the compulsory school. Particular attention will be paid to research into young people's views towards the growing cultural and religious diversity in Iceland because they have grown up in times of these societal changes, and students do not leave their views and attitudes behind when they enter the classroom. The aim is to better understand the new situation of religious education in Iceland and the changes that have been made to the National Curriculum Guide. In the first part of the article actual research into Icelanders attitudes, with a special focus on young people's views. In the second part, the focus is on policy documents, and the changes made to the school legislation and the National Curriculum guide. The purpose is to find out not only how the societal changes in Iceland have influenced the changes made to the school legislation and curricula but also to what extent they are in line with the parents and young people's views and attitudes, and whether their views support the importance of the changes made to the National Curriculum Guide.

\section{The Situation in Iceland: Icelanders' Life Views and Religion in Times of Growing Diversity}

As pointed out above, cultural and religious diversity has grown significantly in recent years in Iceland according to the official statistics. To give a clearer picture of the new religious reality in Iceland, it is useful to look at Icelanders' attitudes towards religious and multicultural matters, and to discuss what conclusions can be drawn from them for policy-making in religious education. In 2015, a survey was conducted on the life views and religious attitudes of people all around Iceland, when they were aged 18-75 years old. In total, 821 people answered the survey. Some of the results are of interest when considering the societal changes in Iceland; for example, around $46 \%$ of the respondents considers themselves believers, $30 \%$ did not, and $24 \%$ could not say whether they are believers or not. At the same time, almost $69 \%$ consider themselves Christians, $23 \%$ claim that they are atheists, and around $9 \%$ support other different religions or beliefs. Further questions show that some of those who consider themselves Christians are so for cultural or moral reasons. When those who considered themselves believers were asked about their attitude toward the existence of God or a higher power, $61 \%$ of them said that they believe in God, and $25 \%$ had a skeptical attitude. The survey also asked about the respondents' attitudes to religious neutrality in preschools, and compulsory schools and about religious activities in public schools. It turns out that $55 \%$ were of the opinion that public preschools and compulsory schools should maintain religious neutrality, but around $25 \%$ disagreed. Also of interest is the fact that around half of those who took a stand were of the opinion that religious activities should be practiced in public schools, and the other half disagreed. Around $26 \%$ did not take a stance (Maskína 2015). 
Unfortunately, there were no questions in the survey about attitudes to religious education in public schools, or about the growing cultural or religious diversity in Iceland. The survey was conducted for Siðmennt, the Icelandic Ethical Humanist Association, and they were more interested in the status of The National Lutheran Church of Iceland, and of different aspects of the relationship between the state and religious and life-view organisations. However, the results reflect the growing diversity in Iceland, as they show that-although two out of three individuals consider themselves Christians-it is for different reasons, and almost one-third of individuals adhere to other religions and life views, or consider themselves atheists.

Although the above study did not focus on religious education in schools, there is one example of such a study in Iceland in recent years. In her study, Júníusdóttir (2014) drew attention to the attitudes of the parents of compulsory school children, with different cultural and religious backgrounds, toward the school's religious education. The purpose of the research was to give parents, as participants in the education of their children, a voice in the debate on the role, emphases, status and importance of religious education as a subject in compulsory schools in Iceland, and to increase the understanding of the religious needs of a diverse group of students in the school. Júníusdóttir's research was based on qualitative methodology that utilized so-called 'objective sampling'. Semi-structured interviews were carried out with seven individuals that had in common that they were parents of compulsory school children, while an emphasis was placed on having as much diversity as possible in the group with respect to cultural and religious background. Júníusdóttir drew the conclusion from the interviews with the parents that their views were characterized by a strong multiculturalism. They emphasized that the Icelandic school system should be in harmony with the growing multiculturalism of the country, and that the school should be a neutral and democratic forum. The view that teaching about religions was one of the important aspects of the democratic role of the school was also strongly expressed by them. They were therefore all of the opinion that religious studies should be a compulsory subject and an important factor in the children's education. When the changes of the National Curriculum Guide were discussed, i.e., that religious studies were now part of social studies, the parents seemed generally positive towards them. It also emerged that many of them considered it natural that a greater emphasis would be placed on Christianity in the education, since it was in a unique position in the country. Their main emphasis was, however, that it was the role of religious education to provide the children with basic knowledge of all of the major religions, so they could form their own views. They also emphasized the importance of the teaching to reduce prejudices and stereotypes, and that it contributed to mutual understanding, tolerance and open-mindedness (Júníusdóttir 2014, pp. 97-99). These results are of interest when exploring what changes have been made to the curricula of religious education, the ways in which they reflect the cultural and religious diversity in the Icelandic society, and the ways in which they respond to the ideas and attitudes of the parents of compulsory school children.

In Iceland, there has been a considerable activity in research into young people and diversity over the last decade. Thus, researchers in Iceland have conducted several studies on young people and multicultural issues. The results of these studies are of interest when discussing the situation in Iceland, and the circumstances and role of education.

Many of the studies focused on the experiences of immigrants and refugees, and the ways in which young people adapt to Icelandic society. Hanna Ragnarsdóttir's qualitative study—conducted in 2011 among immigrant youth in Iceland-shows, for example, that it depends on how young the children were when they came to Iceland. She focused on their experiences of life and work in Icelandic society during the preceding ten years. The findings indicate that the participants in the study had all successfully adapted to Icelandic society and adopted a positive stance toward it. They describe themselves as having mixed identities or as being cosmopolitan. The older participants in the group (aged 20-24) came to Iceland in their adolescence and started compulsory school there. They struggled more in their subsequent studies than the younger participants (aged 16-19), who had been in Icelandic compulsory school most of their lives. The individuals in the younger group were doing well in their studies, and no longer needed support in Icelandic or other subjects. The participants' social 
networks appear to differ between the older and younger groups. Those in the older age group mostly had friends with immigrant backgrounds, while in the younger age group, their friends included Icelanders as well as other immigrants (Ragnarsdóttir 2011). Another qualitative study conducted among sixteen immigrants aged 18-25 showed, in part, that they have either no or few close Icelandic friends. Most respondents reported that contact with Icelandic peers was friendly, but usually not close (Guðmundsson 2013).

There has also been research on prejudice and young people's attitudes toward human rights and civic awareness (Aðalbjarnardóttir 2011; Guðmundsson 2013; Markúsdóttir and Aðalbjarnardóttir 2013; Pétursdóttir 2013; Halldórsdóttir 2016). The results of one study, with a sample of 89 participants, show that hidden prejudices exist in Icelandic society, with the findings suggesting a significant difference between Icelandic and non-Icelandic participants in terms of perceived prejudice and discrimination (Pétursdóttir 2013). Halldórsdóttir (2016) also discusses micro-insults and hidden prejudices in Icelandic society. A report presenting the data and analysis of two surveys conducted in 2013 on behalf of the Multicultural and Information Centre, and the Icelandic Human Rights Centre provides similar results, showing that immigrants experience prejudice when applying for jobs: for example (Arnardóttir and Haraldsson 2014). In Markúsdóttir and Aðalbjarnardóttir (2013) study of nineteen young people, two age groups-15 and 19 years old-were interviewed. The results show, among other things, that the young people felt that learning Icelandic was the key to immigrants' participation in society, and they believed that immigrants should be able to enjoy the same rights as other citizens. The young people also felt that prejudices toward immigrants could keep them from participating in society. Also of interest is that some of the young people made a clear distinction between 'us' and 'them' in their discussion of immigrants, and the analysis of the data indicated the young people's fear of changes in Icelandic culture, religion, and society (Markúsdóttir and Aðalbjarnardóttir 2013). The results of all of these studies show how important it is to deal with the increasing diversity in the Icelandic society in social studies, and consequently in religious education.

Only a few studies have focused specifically on young people's views of life and values. Some of them were carried out in the first decade of the 21st century, and many of them show increasing diversity in young people's life views (Finnbogason and Gunnarsson 2006; Jónsson 2006; Júlíusdóttir 2006; Aðalbjarnardóttir 2007; Gunnarsson 2008; Porsteinsson 2009). One of the studies addressed specially the development of religious diversity in Iceland. Young people aged 19-20 were interviewed, and the results showed that participants' knowledge and experience of religious diversity was rather limited. They seemed to form their ideas from media news, blog discussions, the opinions of parents, teaching and learning in school, and conversations with peers. However, personal experience figured only to a limited extent, and interfaith dialogue featured even less (Porsteinsson 2009).

In 2011, a group of researchers at the University of Iceland's School of Education started a research project with a focus on young people's life views and life values in a multicultural society. The methodological approaches were both quantitative and qualitative. Around 900 upper secondary school students in different schools answered the questionnaire, and this was followed up with focus group interviews in five upper secondary schools, where all together 27 students were interviewed in 2013 and 2014. Most of the 27 participants were born in Iceland and had Icelandic parents. Five participants had foreign backgrounds, were born abroad, and had moved to Iceland when they were in primary school. Most of the participants belonged to The National Lutheran Church of Iceland; three belonged to other religious organizations, and five did not belong to any religious organization. Several articles have been published with the main results (Finnbogason et al. 2011; Gunnarsson 2012; Gunnarsson and Finnbogason 2012; Ragnarsdóttir and Jónsdóttir 2013; Gunnarsson et al. 2015; Gunnarsson et al. 2016; Ragnarsdóttir et al. 2016; Gunnarsson et al. 2018; Ragnarsdóttir et al. 2020). Among the findings of the project is that young people in Iceland seem generally positive toward the growing cultural and religious diversity in society. The results also show that women have a significantly more positive attitude towards cultural and religious diversity than men. Furthermore, participants that had parents with university education showed a significantly more positive attitude 
towards cultural and religious diversity than those who had parents with lower levels of education. The findings show a positive relationship between the attitude towards cultural diversity and the attitude toward religious diversity, indicating that a more positive attitude toward cultural diversity leads to a more positive attitude toward religious diversity (Ragnarsdóttir et al. 2020). Some of the participants maintained that growing diversity is important for society, because it can reduce prejudice and narrow-mindedness. Many of them had friends with different backgrounds, and this did not cause any problems, while others said that their circle of friends was rather homogeneous. However, some of the young people pointed out that it was unfortunate if immigrants isolated themselves in groups and provided little to society. This attitude reflects a majority perspective, as the young people talked about immigrants isolating themselves. They seemed to imply that integration or inclusion is the responsibility of the immigrants, and they seemed not to think of them as being marginalized (Gunnarsson et al. 2018).

In the young people's talk about religion, it appears that the daily life of many of the young people in the study is secularized. That is, religion, religious activity and the church are not significant parts of their daily life, and they look at their own and others' religious views as a private matter. At the same time, the young people are aware of the religious diversity in society and among friends, they agree that it is important to be convinced about one's life view or belief, and many of them are of the opinion that it can help to believe or pray, for example, in times of difficulties (Gunnarsson et al. 2016). The positive attitudes of the respondents towards religious diversity, and the positive relationship between attitudes towards cultural diversity and attitudes toward religious diversity indicate that the young people may be aware of the role religion plays in modern multicultural societies (Ragnarsdóttir et al. 2020). In general, the young people seem to be ready to respect everybody's freedom of belief, and they understand the importance of mutual respect. However, they recognize that prejudice exists in Icelandic society. They claim that negative news often influences people, and such people tend to generalize and have negative views toward ethnic or religious groups. At the same time, they are optimistic that prejudices are decreasing, especially among younger generations. Some of them believe that multiculturalism should be accepted as a normal state, and that equality and human rights should just go without saying (Gunnarsson et al. 2018).

All these studies are important and helpful when discussing the circumstances and role of religious education. They provide insight into the world and attitudes of young people, and into their social and moral competence. This insight is important when discussing policies, emphases and approaches in religious education. As pointed out by many scholars who emphasise a contextual approach in religious education, students do not leave their life views, values and convictions outside the classroom, and the content of religious education is not only data obtained by the teacher but also involves the participants' knowledge and experiences outside the school, and an interactive between the two (Jackson 1997, 2004; Leganger-Krogstad 2003, 2011; Gunnarsson 2008). Therefore, the views and attitudes of young people are important when discussing the content and approaches in religious education in a society of growing diversity. They also provide a basis for discussing whether the emphasis of the National Curriculum is likely to meet the realities and experiences of young people.

\section{Educational Policy and the National Curriculum Guide from 2011}

As previously mentioned, new National Curriculum Guides were prepared for the school system in Iceland, following the Preschool Act (2008), the Compulsory School Act (2008), and the Upper Secondary School Act (2008). In 2011, the general part of the new National Curriculum Guide became effective. In chapter two of The Icelandic National Curriculum Guide for Compulsory schools: General Section (The Ministry of Education, Science and Culture 2011a, pp. 13-24) we find a description of what is called general education. In The Icelandic National Curriculum Guide for Preschools 2011 (The Ministry of Education, Science and Culture 2011b), and in The Icelandic National Curriculum Guide for Upper Secondary Schools: General Section 2011 (The Ministry of Education, Science and Culture 
2011c), there are similar chapters. In these chapters, the educational policy for Iceland is described. One part is the description of the purpose of general education:

"At any given time, general education advances the capacity of the individual for meeting the challenges of everyday life. General education therefore contributes towards the individuals' understanding of their characteristics and abilities and consequently their capacity to fulfil their role in a complex society. It is at the same time both individually and socially oriented." (The Ministry of Education, Science and Culture 2011a, p. 13)

The focus is on making the pupils able to live and fulfill their role in a complex society. This is in line with the main objective of the Preschool Act (2008), the Compulsory School Act (2008), and the Upper Secondary School Act (2008). According to these laws, the role of education is, in collaboration with the home, to promote the comprehensive development of all students and their participation in a continually developing democratic society. The further description of the educational policy that appears in the National Curriculum Guide is based on six fundamental pillars of education, on which the curriculum guidelines are then based. In the preface to the Icelandic Curriculum Guide, Katrín Jakobsdóttir, who vas the Minister of Education, Science and Culture at the time, described the fundamental pillars as the essence of the educational policy:

"The National Curriculum Guide contains the frame and conditions for learning and teaching based on the principles of existing laws, regulations and international conventions. Six fundamental pillars have been developed within this frame and they form the essence of the educational policy. They include the working methods, content and the learning environment at every school level and form important continuity in the Icelandic educational system." (The Ministry of Education, Science and Culture 2011a, p. 5)

This means that the fundamental pillars of education are the key element in the Icelandic school system. They reflect the basic standards of the educational authorities, and are supposed shape the school system from preschool to upper secondary school. The emphasis placed by the authorities on the fundamental pillars is also reflected in the publication of six booklets detailing their contents. The purpose is to help teachers, school administrators and school staff to understand the content of the fundamental pillars, and integrate them into school work (Mennamálastofnun 2012). In that way, the booklets were supposed to be in support of the implementation of the new curriculum guide, and to be of guidance in the daily work of the schools.

According to the National Curriculum Guide, the fundamental pillars are literacy in the widest sense, education towards sustainability, health and welfare, democracy and human rights, equality, and creativity. When explaining the role of the fundamental pillars, the focus is on "social, cultural, environmental and ecological literacy so that children and youth may develop mentally and physically, thrive in society and cooperate with others" (The Ministry of Education, Science and Culture 2011a, p. 14).

In the general section of the curriculum guide, the fundamental pillars are described in detail. Their legal preconditions are specified, for example the Preschool Act (2008), the Compulsory School Act (2008) and the Upper Secondary School Act (2008), but there is also reference to other laws which include legal provisions for education and teaching in the school system, such as the Act on Equal Status and Equal Rights of Women and Men (2008). In addition, a reference is made to international conventions to which Iceland is a party, which create an important basis for the fundamental pillars, such as the United Nations Convention on the Rights of the Child, and the policy of the international institutions of which Iceland is a member. Here, the UNESCO policy on general education and sustainable development is an apt example, as is the Council of Europe policy on democracy and human rights. In addition, the idea of teacher professionalism is taken into account, as well as the developmental work that has been carried out in Icelandic preschools, compulsory schools and upper secondary schools (The Ministry of Education, Science and Culture 2011a, p. 14). All of this forms the 
basis of the standards set by the government, and is emphasized by the Minister of education, Science and Culture to be the framework for the six fundamental pillars. A closer look at them shows that this is the case. The description of the fundamental pillars of education is too extensive to be examined in detail in a short article. However, if we try to outline the main points, it turns out that most of the pillars are related to the concept of critical thinking. The description of literacy is clearly based on that concept, which is exemplified when it says:

"The main objective of literacy is for pupils to become active participants in transforming and rewriting the world by creating their own meaning and responding in a personal and creative manner to what they read with the aid of the media and technology that is available." (The Ministry of Education, Science and Culture 2011a, p. 17)

Henrysson (2013) discusses the concept 'critical thinking', and the fact that it has been included in the National Curriculum Guide, and points out that critical thinking is positive, creative and constructive. He argues that to use critical thinking is to look at a certain issue from every possible angle, and that the adjective 'critical' should not be confused with the verb 'to criticize'. To train students in this type of thinking is to help them to build their own meaning and opinions, rather than having them use critical thinking to tear down the opinions of others. He also emphasizes how critical thinking should encourage us to enjoy our responsibilities as reflective beings. The emphasis of the National Curriculum Guide when defining literacy is in harmony with this when it focuses on the need for students to create their own meaning, and to respond in a personal and creative manner. The same applies to the description of sustainability when it says:

"Education for sustainability encompasses creating a society of collective responsibility where individuals develop as active citizens, conscious of their own values, attitudes and feelings for global impact and equality of all the inhabitants of the earth, for nature and the environment, for democracy, human rights and justice, for equality and multiculturalism, for welfare and health, and for economic development and vision of the future." (The Ministry of Education, Science and Culture 2011a, p. 18)

Here, the focus is on collective responsibility and the students' consciousness of their own values, attitudes and feelings. It is also interesting to note the way in which the description of sustainability refers to many of the other fundamental pillars. Therefore, it seems that sustainability is one of the most important pillars, given that it refers among other things to democracy and human rights, justice and equality, and welfare and health.

The description of democracy and human rights, the third fundamental pillar, refers directly to critical thinking by saying that "education for democracy and human rights is based on critical thinking and reflection on the basic values of society" (The Ministry of Education, Science and Culture 2011a, p. 19). But it is also emphasized that it is essential for democratic schools to take an active part in creating a sustainable society of collective responsibility. Thus, the description of democracy and human rights refers back to sustainability, based on collective responsibility.

According to the curriculum guide's description of equality education, the fourth pillar, one of the tasks is the development of Iceland as a multicultural society, and thus it emphasizes education concerning culture, nationality, languages, religion and values, which is obviously important when it comes to religious education. It also incorporates, among other things, studies of gender and sexual orientation, and emphasis is placed on a social understanding of the nature of disabilities. Therefore, in all school activities, the emphasis is on inclusive education (The Ministry of Education, Science and Culture 2011a, p. 20).

In the description of health and welfare, the focus is on mental, physical and social wellbeing, and the complex interrelation of the individual, their circumstances and the environment. It is emphasized that it is important that schools take into consideration the individual needs of children and youth. Everyone needs an opportunity to enjoy their strengths, which is a key factor in building 
a positive self-image. Close cooperation with parents, healthcare personnel and people from the local community is also stressed, since such cooperation is a prerequisite for success (The Ministry of Education, Science and Culture 2011a, p. 21). Of importance here is the focus on all three factors of mental, physical and social wellbeing, together with individual needs.

The final fundamental pillar is somewhat different from the other, as it speaks of creativity, because it binds together the core elements of all of the fundamental pillars. Thus, it says that it is to encourage reflection, personal education and initiative in educational work. Here, critical thinking is emphasized as a key factor in literacy and creativity, and they are interlinked with the role of critical thinking in democracy. In that way, creativity utilizes ideas and shapes attitudes, values and competence. It is also pointed out that:

"Creativity not only concerns something new and original but also utilizes what already exists. It encompasses task solutions and search for new possibilities. This harmonizes well with education towards sustainability and literacy in the widest sense." (The Ministry of Education, Science and Culture 2011a, p. 22)

If we summarize some of the main points of the National Curriculum Guide's discussion of the fundamental pillars of education, we see some key points that stand out. The students are to be active in transforming and rewriting the world, and to create their own meaning; they should promote a sustainable society, based on collective responsibility; and they should be conscious of their own values, attitudes and feelings. The focus is on democracy, human rights and equality in a multicultural society, and therefore it emphasizes education concerning culture, nationality, languages, religion, and values. In all this, critical thinking is seen as a key factor. This, of course, should shape religious education just like any other school subject.

\section{Religious Education in the Subject Areas Curriculum Guide 2013}

The fundamental pillars of education are all supposed to be visible in the teaching and learning, working methods, organization and development plans of schools, and furthermore, in its relations with its local community (The Ministry of Education, Science and Culture 2011a, p. 14). This implies that the curricula of the subject fields should take account of these fundamental pillars of education. Following the Subject Areas Curriculum Guide of 2013 for compulsory schools, the curricula of individual subjects were merged into larger entities, and religious education thus became a part of social studies. This entails, among other things, that the role of religious education is primarily described in the context of the subjects that are included there (The Ministry of Education, Science and Culture 2013, pp. 200-202).

Keeping in mind that the role of the fundamental pillars refers to social, cultural, environmental and ecological literacy, and that they are supposed to be visible in the teaching and learning of different subjects, it is clear that this would result in significant changes in the main emphases in religious education, compared with older National Curriculums Guides in Iceland. If we look at the social studies in The Icelandic National Curriculum Guide from 2013, we can see that the emphasis has shifted to some extent from a 'substantive' understanding of religion, with emphasis on the substance and traditions of individual religions (where Christianity was in the place of honour), to a 'functional' understanding of religion, with increased emphasis on the cultural and social context and the role of religions (McGuire 1992, pp. 9-15). This does not mean that no attention is given to the substance of the religions, or that the uniqueness of Christianity in Icelandic society is pushed off the table, but rather that the emphasis is increased on the ability of students to explain the diversity of religions and life views, and to analyse their impact on the lives of individuals, groups and societies. The goal is to achieve increased understanding of the diversity of human life and the different backgrounds of people, and respect for the freedom of people to have different beliefs, values, opinions and lifestyles. In this respect, the emphasis of the curriculum guide is obviously on the increased cultural and religious diversity in the Icelandic society. All of this results in the conclusion that a contextual understanding of 
religious education seems to be a more appropriate approach, since religious education is defined as a part of social studies. This is in line with the discussion of Jackson $(1997,2004,2008)$ and Ipgrave $(2003)$ in England, Skeie $(1998,2007)$ and Leganger-Krogstad $(2003,2011)$ in Norway, and Weisse (2008) in Germany. These religious education researchers all stress how important it is for the students to study religions in their cultural context, and that their personal knowledge and experience can contribute to religious education in schools, together with the syllabus.

The role of religious education in the 2013 National Curriculum Guide is extensive, and it includes many topics. The overall aim is that it will increase the understanding of dominant religions and different religious traditions, with tolerance and open-mindedness as guiding principles. This shows that the religious education curriculum has been influenced by the increased religious diversity in Iceland. Social studies learning outcomes describe more fully what is being aimed at, and even there, we can see that the growing diversity is addressed. The learning outcomes are classified into three main categories; the experiential world and the ability of students to understand reality, the mental world and the ability of students to understand themselves, and the social world and the ability of students to form and develop their relationships with others (The Ministry of Education, Science and Culture 2013, p. 201). These three are in good agreement with the emphasis placed in the National Curriculum Guide's discussion of the fundamental pillars of education, with a focus on the students' ability to transform and rewrite the world, to create their own meaning, and to promote the consciousness of their own and others values, attitudes and feelings, and collective responsibility.

In the first category about the experiential world, faith and religion-and their role in society-are in focus, among other things. Students should be able to consider the interaction of society, politics, nature, religion and life views over time, in the context of the local community and globalization; they should be able to work on and analyze tasks which concern religion, life views and morals, and which are connected to questions about the meaning and purpose of life, and they should be able to explain the diversity of religions and life views, and analyze their effects upon individuals, groups and communities. Emphasis is also placed on the ability of students to understand narratives, traditions, doctrines, festivals, customs and symbols of Christianity and the other major religions of the world, and their ability to analyze the impact of the Bible and the sacred writings of other major religions on culture and communities.

In the part of the goals which relates to the mental world and understanding of self, it is stated, among other things, that the student should be able to reflect upon and express who he is in his own eyes and in the eyes of others, and explain how his identity is shaped by his environment and residence, politics and social conditions, history and culture, religions and life views. Emphasis is also placed on the ability to argue for the value of positive life views, virtues and values as an important part of a healthy sense of self.

Finally, in the category of goals which relates to the social world, it is stated, among other things, that students should be able to explain, with examples, the diversity of human life and the different backgrounds of people; to respect the freedom of people to have different beliefs, values, opinions and lifestyles; and to evaluate opinions and information, and respond to them in a non-prejudiced and equitable manner (The Ministry of Education, Science and Culture 2013, pp. 200-209).

When we look at these goals and compare them with the role of the fundamental pillars of education, we can see that they reflect social, cultural, environmental and ecological literacy, and children's and youth's mental and physical development, so that they can thrive in society and cooperate with others. The goals also reflect the emphasis of the fundamental pillars on the promotion of sustainability, equality, human rights and democracy, and the promotion of well-educated and healthy citizens, both for participation in and for changing and improving society. On this basis, it can be concluded that the National Curriculum Guide reflects, in many ways, the societal changes that have taken place in recent years in Iceland, both generally and specially in social studies and religious education. The question is whether and how schools have achieved these goals in the years that have passed since the introduction of the national curriculum. In that regard, this new situation of religious education in Iceland calls 
for more research in the field. When the proportion of religious education within the social studies subject area in the National Curriculum Guide from 2013 is examined, by going through the learning outcomes in the 10th grade in the Compulsory School, we can see that learning outcomes connected to religious education amount to almost $20 \%$ of the total learning outcomes in social studies. This is about the same as in other subjects within the social studies, such as history and geography, life skills education, etc. The problem is that social studies only get $11.46 \%$ of the students' weekly lesson time in the compulsory school (The Ministry of Education, Science and Culture 2011a, p. 50). Keeping in mind all of the different subjects within social studies, and considering all of the learning outcomes and the material to be examined, it is obvious that the allocated time for social studies is too little.

The implicit risk related to the 2013 Icelandic National Curriculum Guide is perhaps that the content elements of the religions will be neglected to some extent, and therefore the knowledge and understanding needed to achieve the high aspirations of the curriculum guide will be lacking. The result will primarily depend on the ways in which the individual schools and teachers use the material. Another risk is that religious education will be left out when it comes to teaching about the many topics of social studies, because of the division of time between the different subjects and subject areas in compulsory school, and because of the limited time for social studies (The Ministry of Education, Science and Culture 2011a, p. 50). According to the National Curriculum Guide, the schools are intended to establish their own school curriculum. In the National Curriculum Guide: General Section, from 2011, we find instructions about school curriculum guides:

"Each school devises a school curriculum guide. The school curriculum guide details how it makes use of the latitude for decisions that are stipulated in law, regulations, the National Curriculum Guide and the school policy of the relevant local government." (The Ministry of Education, Science and Culture 2011a, pp. 64-65)

The school curriculum guide is intended, among other things, to provide information concerning some items. One of the items that are listed is the "objectives of education with regard to the provisions of the National Curriculum Guide" (The Ministry of Education, Science and Culture 2011a, p. 65). This implies that it is important to examine what happens to religious education when different schools are designing their school curriculum guide in social studies, and to see what happens to religious education there. This also implies that it is important to study what happens in different schools and classes when the teachers have to choose what they intend to emphasize in the teaching of social studies, and the approaches that they use, especially in religious education. It is also interesting to find out how teachers feel prepared for the changes that have been made to the curriculum. In 2008, it was decided by The Act on the Education, Competency and Recruitment of Teachers and Administrators of Preschools, Compulsory Schools and Upper Secondary Schools (2008) that, instead of three-year compulsory school teacher education, there would be a requirement for five years of education, i.e., a Master's degree. This was put in place as a part of the new legislation for the school system in Iceland in 2008, and therefore not as a response to the new curriculum in 2011/2013. However, this change did not take effect until 2011, at the same time as the new National Curriculum Guide.

\section{Conclusions}

Public statistics in Iceland, and research into the views and attitudes of Icelanders, show the growing cultural and religious diversity in Iceland, and shed light on the new situation of religious education in Iceland. Of special interest are the studies of young peoples' attitudes, because school students do not leave their life views, values and convictions outside the classroom. Young people in Iceland grow up in a society that is no longer homogeneous, but is increasingly shaped by the growing diversity. The views of the young peoples in the studies presented above clearly testify to this. The young people were, in general, positive toward the growing cultural and religious diversity in society, and they seem to be ready to respect everybody's freedom of belief, and they understand the importance of mutual respect. However, some of the young people made a sort of distinction between 
'us' and 'them' when they seemed to imply that integration or inclusion is the responsibility of the immigrants, and were not aware of the fact that they might be marginalized. Although they recognized that prejudice exists in Iceland, they were at the same time optimistic that prejudices were decreasing, especially among their own generation. Here, the question arises whether they are aware of the hidden prejudices that exist in Icelandic society. Also of interest is the fact that the young people seem to be aware of the role that religion plays in modern multicultural societies, even if their daily lives seem to be secularised. It is a matter of concern if many of the young people's knowledge and experience of religious diversity is rather limited, and if they formulate their ideas and views mainly from media news, blog discussions, conversations with peers, etc. These results are of help to understand the circumstances and the role of religious education in times of rapid societal changes. The views and attitudes of the young people support the importance of many of the learning outcomes in the Icelandic National Curriculum Guide (The Ministry of Education, Science and Culture 2013, pp. 200-209), such as being able to explain, with examples, the diversity of human life and the different backgrounds of people, and to respect the freedom of people to have different beliefs, values, opinions and lifestyles, as well as to evaluate opinions and information, and to respond to them in a non-prejudiced and equitable manner. They also demonstrate the importance of religious education, and raise questions about what approaches are suitable.

The views of the parents of compulsory school children are also important in this regard, when they stress that the role of religious education is to provide the children with a basic knowledge of all major religions, so that they can form their own views. They also emphasized that the teaching and learning is important in order to reduce prejudices and stereotypes, and that they can contribute to mutual understanding, tolerance and open-mindedness. In that case their views are in line with the overall aim of the curriculum guide.

The examination of the Icelandic National Curriculum Guide shows that radical changes have been made to religious education, compared with older curriculum guides. We can see that the changes have been strongly influenced by the increasing diversity in Icelandic society over the last two decades. The focus has moved from a substantial to a contextual understanding of religions and approaches in religious education. It is also of interest to see the way in which religious education as a part of social studies is intended to reflect the emphasis of the six fundamental pillars of education, where social, cultural, environmental and ecological literacy is in focus, and the students are to be active in transforming and rewriting the world, and to create their own meaning, with a consciousness of their own and others' values, attitudes and feelings. It is obvious that religious education can contribute, with its focus on the students' experiential, mental and social worlds, especially when it comes to social and cultural literacy in times of growing diversity. The Icelandic National Curriculum Guide made religious diversity a key issue in religious education, as the overall aim is to increase the understanding of dominant religions and different religious traditions, with tolerance and open-mindedness as guiding principles. Although religious education has a similar proportion to other subjects within the social studies according to the curriculum guide, this is no guarantee that religious education will have adequate space in the timetable of different schools. The main question is then what has happened in the teaching and learning of religious education in the schools since the National Curriculum Guide came into force in 2013, but there is a lack of research in this area. Although we have a fairly clear picture of the way in which the societal changes in Iceland have influenced the policy making, legislation and curricula, there is obviously a need for such research to get a clearer picture of the ways in which religious education has developed in the school system in Iceland over the last few years. There is also a need for research into how teachers are, and feel, prepared for the teaching, according to the changes made to the curriculum guide.

Funding: This research received no external funding.

Conflicts of Interest: The author declares no conflict of interest. 


\section{References}

Act on Equal Status and Equal Rights of Women and Men. 2008. No. 10/2008. Available online: https://www.government.is/lisalib/getfile.aspx?itemid=90bec9b4-0275-11e8-9425-005056bc530c (accessed on 15 September 2020).

Aðalbjarnardóttir, Sigrún. 2007. Virðing og umhyggja: Ákall 21. aldar. [Respect and Concern: The Challenge of the 21st century]. Reykjavík: Heimskringla-Háskólaforlag Máls og Menningar.

Aðalbjarnardóttir, Sigrún. 2011. Borgaravitund ungs fólks ílýđræðissamfélagi. [Young People's Civic Engagement in Democratic Societies]. Reykjavík: Rannsóknarsetrið Lífshættir Barna og Ungmenna-Félagsvísindastofnun og Menntavísindastofnun Háskóla Íslands.

Arnardóttir, Elsa, and Rúnar Helgi Haraldsson. 2014. Origin and Multiple Discrimination. Fjölmenningarsetur: Mannréttindaskrifstofa Íslands and European Commission.

Compulsory School Act. 2008. No. 91, 2008 [Lög um grunnskóla nr. 91/2008]. Available online: https:/www.government.is/media/menntamalaraduneyti-media/media/frettatengt2016/91_2008Compulsory-School-Act-ENGLISH-Uppfaert-Jan-2017.pdf (accessed on 17 February 2020).

Finnbogason, Gunnar E., and Gunnar J. Gunnarsson. 2006. A need for security and trust: Life interpretation and values among Icelandic teenagers. In Nordic Perspectives on Religion, Spirituality and Identity. Yearbook of the Department of Practical Theology. Edited by Kirsi Tirri. Helsinki: University of Helsinki, pp. 271-84.

Finnbogason, Gunnar E., Gunnar J. Gunnarsson, Halla Jónsdóttir, and Hanna Ragnarsdóttir. 2011. Lífsviðhorf og gildi: Viðhorfskönnun meðal ungs fólks í framhaldsskóla á Íslandi. Ráðstefnurit Netlu—Menntakvika 2011. Available online: http://netla.hi.is/menntakvika2011/009.pdf (accessed on 25 March 2020).

Gallup. 2020. Traust til Stofnana. Available online: https:/www.gallup.is/nidurstodur/thjodarpuls/traust-tilstofnana/ (accessed on 6 April 2020).

Guðmundsson, Gestur. 2013. Innflytjendur í íslenskum framhaldsskólum [Immigrants in upper-secondary education in Iceland]. Netla-Veftímarit um uppeldi og menntun. Sérrit-Rannsóknir og skólastarf. Available online: http://netla.hi.is/serrit/2013/rannsoknir_og_skolastarf/003.pdf (accessed on 30 March 2020).

Gunnarsson, Gunnar J. 2008. I Don't Believe the Meaning of Life Is All that Profound. A study of Icelandic Teenagers' Life Interpretation and Values. Ph.D. thesis, Stockholm University, Stockholm, Sweden.

Gunnarsson, Gunnar J. 2012. Ungt fólk og trúarbrögð. Rannsókn á lífsviðhorfum og gildismati framhaldsskólanema [Young people and religion. A study of upper secondary school student's life views and life values]. Ritröð Guðfræðistofnunar 34: 50-76.

Gunnarsson, Gunnar J., and Gunnar E. Finnbogason. 2012. Margbreytileiki og samstaða. Niðurstöður úr rannsókn á viðhorfum framhaldsskólanema á tímum margbreytileika [Diversity and solidarity. Results from a study of the attitudes of upper secondary school students in times of diversity]. Netla-Veftimarit um uppeldi og menntun. Háskóli Î́slands, Menntavísindasvið. 16 bls. December 31. Available online: http://netla.hi.is/menntakvika2012/007.pdf (accessed on 25 March 2020).

Gunnarsson, Gunnar J., Gunnar E. Finnbogason, Hanna Ragnarsdóttir, and Halla Jónsdóttir. 2015. Friendship, diversity and fear-Young people's life views and life values in a multicultural society. Nordidactica-Journal of Humanities and Social Science Education 2: 94-113. Available online: http://kau.diva-portal.org/smash/ record.jsf?pid=diva2\%3A843896\&dswid=5153 (accessed on 25 March 2020).

Gunnarsson, Gunnar J., Hanna Ragnarsdóttir, Gunnar E. Finnbogason, and Halla Jónsdóttir. 2016. Young People's Views on Religions in a Multicultural Society. Usuteadusliku Ajakirja-Theological Journal of Estonian Academic Theological Society, University of Tartu. Estonia 69: 93-109. Available online: http://usuteadus.ee/wordpress/?page_id=862\&lang=et (accessed on 27 March 2020).

Gunnarsson, Gunnar J., Hanna Ragnarsdóttir, Gunnar E. Finnbogason, and Halla Jónsdóttir. 2018. Young People’s Discourse about Diversity, Tolerance, Prejudice and Human Rights in a Multicultural Society. In Icelandic Studies on Diversity and Social Justice in Education. Edited by Samuel Lefever Ragnarsdóttir. Newcastle: Cambridge Scholars Publishing, pp. 105-29.

Halldórsdóttir, Brynja Elísabeth. 2016. Ég er að fara á fund með pessari stúlku parna. Öráreitni sem birtingamynd fordóma í íslensku samfélagi [I'm going to a meeting with this girl there. Micro-insults as embodiment of prejudices in Icelandic society]. In Skóli margbreytileikans. Menntun og manngildi i kjölfar Salamanca. Edited by Dóra S. Bjarnason, Hermína Gunnpórsdóttir and Ólafur Páll Jónsson. Reykjavík: Háskólaútgáfan—Rannsóknastofa um Skóla án Aðgreiningar, pp. 185-207. 
Henrysson, Henry Alexander. 2013. Skoðanir, siðferði, samfelag. Enn um gagnrýna hugsun [Opinions, morals, society. Still about critical thinking]. Netla-Veftimarit um uppeldi og menntun. August 20. Available online: http://netla.hi.is/greinar/2013/ryn/001.pdf (accessed on 19 September 2020).

Ipgrave, Julia. 2003. Dialogue, Citizenship and Religious Education. In International Perspectives on Citizenship, Education and Religious Diversity. Edited by Robert Jackson. London: RoutledgeFalmer, pp. 147-68.

Jackson, Robert. 1997. Religious Education: An Interpretive Approach. London: Hodder \& Stoughton.

Jackson, Robert. 2004. Rethinking Religious Education and Plurality: Issues in Diversity and Pedagogy. London: RoutledgeFalmer.

Jackson, Robert. 2008. Contextual Religious Education and the Interpretive Approach. British Journal of Religious Education 30: 13-24. [CrossRef]

Jónsson, Friðrik H. 2006. Gengur lífsgildakvarði Schwartz á Íslandi?" [Does the Schwartz Values Scale work in Iceland?]. In Rannsóknir i félagsvísindum VII. Edited by Úlfar Hauksson. Reykjavík: Háskóli Íslands, Félagsvísindadeild, pp. 549-58.

Júlíusdóttir, Sigrún. 2006. Fjölskyldubreytingar, lífsgildi og viðhorf ungs fólks [Family changes, life values and attitudes of young people]. In Rannsóknir í félagsvísindum VII. Edited by Úlfar Hauksson. Reykjavík: Háskóli Íslands, Félagsvísindadeild, pp. 211-24.

Júníusdóttir, Móeiður. 2014. Hlutverk trúarbragðafræðslu í íslensku fjölmenningarsamfélagi: Viðhorf foreldra grunnskólabarna [The role of religious education in multicultural society in Iceland: Attitudes of parents of children in the compulsory school]. Master's thesis, University of Iceland, Reykjavik, Iceland.

Leganger-Krogstad, Heid. 2003. Dialogue among Young Citizens in a Pluralistic Religious Education Classroom. In International Perspectives on Citizenship, Education and Religious Diversity. Edited by Robert Jackson. London: RoutledgeFalmer, pp. 170-90.

Leganger-Krogstad, Heid. 2011. The Religious Dimension of Intercultural Education: Contributions to a Contextual Understanding. Münster: LIT Verlag.

Markúsdóttir, Margrét A., and Sigrún Aðalbjarnardóttir. 2013. Viðhorf ungmenna til mannréttinda innflytjenda og móttöku flóttamanna" [Young people's attitudes towards the human rights of immigrants and refugees]. Uppeldi og Menntun 22: 77-100.

Maskína. 2015. Lífsskoðanir Íslendinga og trú [Icelanders life views and beliefs]. Available online: http://sidmennt. is/wp-content/uploads/L\%C3\%ADfssko\%C3\%B0anir-\%C3\%8Dslendinga-Si\%C3\%B0mennt.pdf (accessed on 10 September 2020).

McGuire, Meredith B. 1992. Religion. The Social Context, 3rd ed. Belmont: Wadsworth Publishing Company.

Mennamálastofnun. 2012. Ritröð um grunnpætti menntunar [Booklets on the fundamental pillars of education]. Available online: https://mms.is/namsefni/laesi-rit-um-grunnthaetti-menntunar-rafbok (accessed on 16 September 2020).

Pétursdóttir, Guðrún. 2013. Birtingarmyndir dulinna fordóma og mismunun í garð innflytjenda á Íslandi" [The embodiment of hidden prejudice and discrimination against immigrants in Iceland]. Íslenska pjóðfélagið 4: 27-38.

Porsteinsson, Pétur B. 2009. Samtal við framandi ... Af hugmyndum tvítugra Íslendinga um fjöltrúarlegar aðstæður. [Conversations with foreigners ... Ideas of 20-year-old Icelanders about multi-religious situations in Iceland]. Húsavík: Lífsmótun.

Preschool Act. 2008. No. 90, 2008 [Lög um leikskóla nr. 90/2008]. Available online: https://www.government. is/media/menntamalaraduneyti-media/media/frettatengt2016/Preschool-Act-No-90-2008.pdf (accessed on 17 February 2020).

Ragnarsdóttir, Hanna. 2008. Collisions and Continuities: Ten Immigrant Families and Their Children in Icelandic Society and Schools. Saarbrücken: VDM Verlag Dr. Müller.

Ragnarsdóttir, Hanna. 2011. Líf og störf ungra innflytjenda: Reynsla ungmenna af tíu ára búsetu á Íslandi" [Lives and work of young immigrants: Experiences from ten years of residence in Iceland]. Uppeldi og menntun 20: 53-68.

Ragnarsdóttir, Hanna, and Halla Jónsdóttir. 2013. Samskipti ungs fólks í fjölmenningarsamfélagi. Tímarit um menntarannsóknir 10: 104-22. Available online: https:/timarit.is/page/6689489\#page/n105/mode/2up (accessed on 17 March 2020). 
Ragnarsdóttir, Hanna, Gunnar J. Gunnarsson, Gunnar E. Finnbogason, and Halla Jónsdóttir. 2016. Viðhorf ungmenna í íslensku fjölmenningarsamfélagi til menningar- og trúarlegs margbreytileika. Tímarit um uppeldi og menntun 25: 219-38. Available online: https://ojs.hi.is/tuuom/article/view/2437 (accessed on 27 March 2020).

Ragnarsdóttir, Hanna, Halla Jónsdóttir, Gunnar J. Gunnarsson, and Gunnar E. Finnbogason. 2020. Diversity, Religion and Tolerance. Young Adults' Views on Cultural and Religious Diversity in a Multicultural Society in Iceland. Religion E Education. [CrossRef]

Skeie, Geir. 1998. En Kulturbevisst Religionspedagogikk. Trondheim: Norges Teknisk-Naturvetenskaplige Universitet.

Skeie, Geir. 2007. Religion and Education in Norway. In Religion and Education in Europe. Developments, Contexts and Debates. Edited by Robert Jackson, Siebren Miedema, Wolfram Weisse and Jean-Paul Willaime. Münster: Waxman Verlag, pp. 221-42.

Statistics Iceland. 2020a. Immigrants $15.2 \%$ of the population of Iceland. Available online: https://www.statice.is/ publications/news-archive/inhabitants/immigrants-and-persons-with-foreign-background-2020/ (accessed on 19 October 2020).

Statistics Iceland. 2020b. Populations by religious and life stance organisations 1998-2020. Available online: https://px.hagstofa.is/pxen/pxweb/en/Samfelag/Samfelag_menning_5_trufelog/MAN10001.px (accessed on 19 October 2020).

The Act on the Education, Competency and Recruitment of Teachers and Administrators of Preschools, Compulsory Schools and Upper Secondary Schools. 2008. No 87/2008. Available online: https://www.icetra.is/media/english/Act-on-the-education-and-recruitment-of-teachers--No-87_ 2008-nr.-87-Uppfaerd-thyding-januar-2017.pdf (accessed on 21 September 2020).

The Ministry of Education, Science and Culture. 2011a. The Icelandic National Curriculum Guide for Compulsory schools: General Section. Available online: https://www.stjornarradid.is/verkefni/menntamal/namskrar/\#Tab0 (accessed on 17 February 2020).

The Ministry of Education, Science and Culture. 2011b. The Icelandic National Curriculum Guide for Preschools. Available online: https://www.stjornarradid.is/verkefni/menntamal/namskrar/\#Tab3 (accessed on 17 February 2020).

The Ministry of Education, Science and Culture. 2011c. The Icelandic National Curriculum Guide for Upper Secondary Schools: General Section. Available online: https://www.stjornarradid.is/verkefni/menntamal/namskrar/\#Tab1 (accessed on 17 February 2020).

The Ministry of Education, Science and Culture. 2013. The Icelandic National Curriculum Guide for Compulsory Schools—With Subjects Areas. Available online: https://brunnur.stjr.is/ mrn/utgafuskra/utgafa.nsf/xsp/.ibmmodres/domino/OpenAttachment/mrn/utgafuskra/utgafa.nsf/ E7DE015E63AA2F2C00257CA2005296F7/Attachment/adalnrsk_greinask_ens_2014.pdf (accessed on 17 February 2020).

Upper Secondary School Act. 2008. No. 92, 2008 [Lög um framhaldsskóla nr. 92/2008]. Available online: https://www.government.is/media/menntamalaraduneyti-media/media/law-and-regulations/UpperSecondary-Education-Act-No.-92-2008.pdf (accessed on 17 February 2020).

Weisse, Wolfram. 2008. Difference without discrimination: Religious education as a field of learning for social understanding. International Perspectives on Citizenship, Education and Religious Diversity 37: 191-208.

Publisher's Note: MDPI stays neutral with regard to jurisdictional claims in published maps and institutional affiliations.

(C) 2020 by the author. Licensee MDPI, Basel, Switzerland. This article is an open access article distributed under the terms and conditions of the Creative Commons Attribution (CC BY) license (http://creativecommons.org/licenses/by/4.0/). 